\title{
Cytokine-induced killer cell therapy- associated idiopathic thrombocytopenic purpura: rare but noteworthy
}

\begin{abstract}
Idiopathic thrombocytopenic purpura (ITP) is characterized by a diminished platelet count, an autoimmune condition with antibodies against platelets and an increased tendency to bleed. The association between ITP and solid tumors is uncommon. Cytokine-induced killer (CIK) cell therapy is a well tolerated and promising cancer treatment with minimal toxicity. For the first time, CIK cell therapy was reported to be followed by ITP. The mechanism through which CIK induces ITP remains unclear. Imbalanced ratio of Th cells, decreased numbers or impaired function of Treg cells and excessive secretion of cytokines inducing abnormal activation of B cells may be among the possible reasons. Therefore, a better understanding of this rare condition will require further investigation of these cases.
\end{abstract}

First draft submitted: 3 Feb 2016; Accepted for publication: 20 May 2016; Published online: 3 August 2016

Keywords: CIK • immunotherapy $\bullet$ ITP $\bullet$ solid tumor

\section{Background}

The current incidence rate of idiopathic thrombocytopenic purpura (ITP) in adults is 3.3 per 100,000 patients each year and the median diagnosed age is 56-60 [1]. ITP is a syndrome with poorly understood pathogenesis and most cases are asymptomatic [2]. If the platelet count falls below 20 $\times 10^{9} / \mathrm{l}$, extremely low platelet count may lead a petechiae of skin and bleeding in the mucous membranes or internal organs [3]. There are no definite clinical symptoms or laboratory parameters to establish diagnosis for ITP [4]. Therefore, the diagnosis of ITP requires the exclusion of other etiologies, which is often difficult $[4,5]$. Antibodies against platelets may be detectable in approximately $60 \%$ of ITP patients [6]. High levels of immunoglobulin G (IgG) or immunoglobulin $\mathrm{M}(\mathrm{IgM})$ antiplatelet antibodies are often found in patient's peripheral blood plasma [7]. Examination of bone marrow may show megakaryocytes to be normal or increased, and occasionally, an increased number of immature megakaryocytes are present. Ultra-structural examination may provide some evidence of megakaryocyte apoptosis [8].

Cancer, the leading cause of death worldwide, has seen increased incidence in the past decades [9]. However, the association between ITP and solid tumors has been rarely described. We collected all 79 published cases of ITP associated with solid tumors. The most common cases of tumor associated ITP were found in breast [10-13], lung [14-18] and urinary system [19-22].

Recently, immunotherapy has emerged as a promising approach for cancer treatment [23]. Cytokine-induced killer (CIK) cells are a heterogeneous type of efficient immune effector cells with potent stronger and broader spectrum antitumor activity [24]. Studies showed that CIK cell therapy was minimally toxic, well tolerated and did not have any dose-limiting toxicities [25]. To our knowledge, incidence of ITP during CIK cell therapy has not been reported.
Xiaomin $\mathrm{Fu}^{* \neq, 1,2,}$, Yong Zhang ${ }^{\ddagger 1}$, Quanli Gao' ${ }^{1}$, Jizhen Lin $^{3}$, Qinxian Zhang', Benling $\mathrm{Xu}^{4}$ \& Yongping Song ${ }^{5}$ 'Department of Cancer Biology Immunotherapy, The Affiliated Cancer Hospital of Zhengzhou University, Zhengzhou University, Henan 450000, China

${ }^{2}$ Basic Medical College of Zhengzhou University, Zhengzhou University, Henan 450000, China

${ }^{3}$ Department of Otolaryngology, Medical School, University of Minnesota, Twin Cities Campus, Minneapolis, MN 55414, USA

${ }^{4}$ Department of Key Lab, The Affiliated Cancer Hospital of Zhengzhou University, Zhengzhou University, Henan 450000, China

${ }^{5}$ Henan Institute of Hematology, The Affiliated Cancer Hospital of Zhengzhou University, Zhengzhou University, Henan 450000, China *Author for correspondence: fuxiaomin0880@126.com

${ }^{\ddagger}$ Authors contributed equally 
In our hospital, almost 3500 patients received more than 15,000 transfusions of autologous CIK cell therapy during the past 6 years. Two cases of ITP associated with CIK cell therapy were encountered in our department. This may be the first case report examining the correlation between ITP and CIK cell therapy in solid tumors.

\section{Case presentation}

Case one

A 41-year-old woman, presenting with recurrent episodes of left chest fullness and cough without sputum, was admitted to our hospital in August of 2010. Clinical examination found reduction of left lung respiratory sounds and small rhonchi by auscultation. No other system disorders and medication history were previously reported. Pathologic diagnosis was lung adenocarcinoma and TNM stage is IV (T4N2M1a). The patient accepted GP regimen chemotherapy as initial management (gemcitabine $1250 \mathrm{mg} / \mathrm{m}^{2}$ days 1 and 8 ; cisplatin $50 \mathrm{mg} / \mathrm{m}^{2}$ days $1,8,15$ by intraplural injection). After one cycle of chemotherapy, the patient's symptoms were alleviated to some extent and the pleural effusion disappeared by CT scan findings, however, the mass and enlarged mediastinal lymph nodes were almost the same as before (Figures $1 \& 2$ ). The following therapy was adjusted to TP regimen chemotherapy plus CIK immunotherapy (paclitaxel $175 \mathrm{mg} / \mathrm{m}^{2}$ day 1 ; cisplatin $25 \mathrm{mg} / \mathrm{m}^{2}$ days $2-4$ ). CIK cells were prepared as before: the peripheral blood mononuclear cells were isolated from $50 \mathrm{ml}$ blood of the patient 3 days prior to chemotherapy, cultured in medium (GT-T551, Takara) with the presence of human IFN- $\gamma$, IL-2 and anti-CD3 monoclonal antibody (MAb). The cells were incubated in a humidified atmosphere with $5 \% \mathrm{CO}_{2}$ at $37^{\circ} \mathrm{C}$. On days $12-14$, the cells were harvested and analyzed for phenotype and cytotoxicity. Then CIK cells were ready to be transfused in 2-4 days after chemotherapy. The phenotype analysis of the patient's CIK cells was presented as Table 1. After two cycles of chemotherapy combined with CIK cell therapy, the patient's symptoms were alleviated noticeably. CT scan revealed that the mass was diminished significantly (Figure 3). The objective response rate was partial remission (PR), valued by Response Evaluation Criteria in Solid Tumors (RECIST). Unavoidably, every cycle of chemotherapy could cause grade 2 myelosuppression such as neutropenia and thrombocytopenia. Moreover, the platelet count was reduced significantly to $13 \times 10^{9} / 1$ accompanied by scattered petechiae on the skin of bilateral lower limb after the third-cycle therapy. Two weeks later, the total wright blood cells were returned to a normal level by using granulocyte colony stimulating factors (G-CSF). Otherwise, the platelet count remained less than $30 \times 10^{9} / 1$ and this situation lasted for two months. 63 days later, the platelet count hovered around $18 \times 10^{9} / 1$, still low and as other conditions might exist, ITP was especially doubted. Bone marrow aspiration and biopsy was performed. The results revealed too few platelets, the megakaryocyte count was 31 and of a predominantly granular type. Advanced examination of platelet antibody (PA) indicated PAIgM was higher than normal (Table 2). Diagnosis of ITP was confirmed. Methylprednisolone was used with the dose of $80 \mathrm{mg}$ per day. After 5 consecutive days usage, the patient's platelet count rose to 129 $\times 10^{9} / \mathrm{l}$. With the corticosteroid dosage tapered off, platelet count maintained in the normal range.

\section{Case two}

In December 2012, a 63-year-old female presented to our hospital with the symptoms of anorexia and dysuria. Physical examination was negative. No system diseases and drug history were previously reported. Abdominal ultrasound showed a large mass $(124 \mathrm{~mm}$ x $84 \mathrm{~mm}$ ) in the right kidney. CT scan indicated a large soft tissue lump in the middle zone of the right kidney may be considered renal carcinoma. Multiple enlarged perirenal lymph nodes were recognized as metastases. In addition, multinodular pulmonary lesions were observed, another site of metastasis. Bone scintigraphy results did not conclusively show a metastatic lesion on the second lumbar vertebra. There were no indications for nephrectomy and the patient denied kidney biopsy. Final pathological results due to a progressively enlarged neoplasm located at the mandibular central incisor gingiva. Pathology confirmed the tumor originated from mesenchymal tissue and epithelial components of the kidney. The patient underwent three courses of CIK cell therapy, on 16th January, 31st January and 11th March in 2013. CIK cell culture protocols were the same as described above. During every course 3.9-4.5 $\times 10^{9}$ CIK cells were transfused to the patient (Table 3 ). The primary complete blood count test on 24 January of 2013 revealed that platelet count was $74 \times 10^{9} / 1$. However, the platelet count decreased to $40 \times 10^{9} / 1$ when the neoplasm ablation was done on 1st March, 2013. 5 days later, a mass reappeared in the same location and scattered hemorrhagic spots on bilateral inner thighs were observed. Advanced examination of antiplatelet antibody levels showed the PAIgG level was approximately triple the upper limit of normal (Table 4). Bone marrow aspiration and biopsy was performed on 6th March, which revealed aporadic platelets, accompanied by an increased number of megakaryocytes, most of which were granular type. We reexamined the platelet count on 11th March and 
it had risen to $74 \times 10^{9} / 1$. The diagnosis of ITP was made and an undeniable link between ITP and CIK cell transfusion was considered. The CIK cell therapy was terminated and the patient refused to accept further antitumor therapies.

\section{Conclusion}

ITP is an autoimmune condition with antibodies detectable against several platelet surface antigens. Due to the destruction of platelets by these antibodies (especially $\operatorname{IgG}$ ), platelet count is low. Its onset can be primary or secondary to infections, tumors or other factors. Studies suggest ITP patients have an increased risk of thrombosis, as the seriously decreased platelet count correlates with the development of thrombosis [26,27]. There is no direct relationship between platelet count and bleeding severity [27].

Laboratory studies showed detectable antiplatelet antibodies in $60 \%$ of patients. The antibodies are often derived from auto-reactive B cells and against platelet membrane glycoproteins IIb-IIIa or Ib-IX, which are the type of IgG [28]. Thrombocytopenia occurs due to the Fc-dependent platelet clearance in the spleen and megakaryocyte apoptosis. Furthermore, the antibodies target the megakaryocytes, impairing platelet production and finally leading to diminished peripheral platelet count $[29,30]$. Measurement of platelet associated antibodies offers $78-92 \%$ specificity of ITP diagnosis, however, the sensitivity ranges from 49 to $66 \%$ [31]. Thus, the positive predictive value for diagnostic utility remains limited.

CIK cells are a heterogeneous population of immune effector cells which feature mixed $\mathrm{T}$ and Natural Killer (NK) cells. Predominantly, the phenotype is $\mathrm{CD}^{+} \mathrm{CD} 56^{+} \mathrm{T}$ lymphocytes. Recent clinical research, primarily in Asia, has shown CIK cell immunotherapy can significantly improve progression-free survival (PFS) and overall survival (OS) in multiple types of solid tumor, especially in patients with liver, gastric, kidney and lung cancers [32-36].

Clinical studies indicated the most common adverse events (AEs) were transient fever, chills and fatigue [24,37]. Further side effects included mild hypotension, headache, nausea, vomiting, malaise, dizziness, conjunctivitis, keratitis, rash and injection site infection $[24,38]$. Most patients with AEs needed no medical interventions. The patients with severe AEs only needed treatment with simple symptomatic measures such as anti-inflammatory, anti-emetic and antibacterial medications [33]. The rare but severe AEs involved anaphylactic shock, tumor lysis syndrome, arthralgia, acute and chronic graft versus host disease $($ GVHD) $[24,37]$. No CIK cell therapy associated with ITP cases are reported yet.

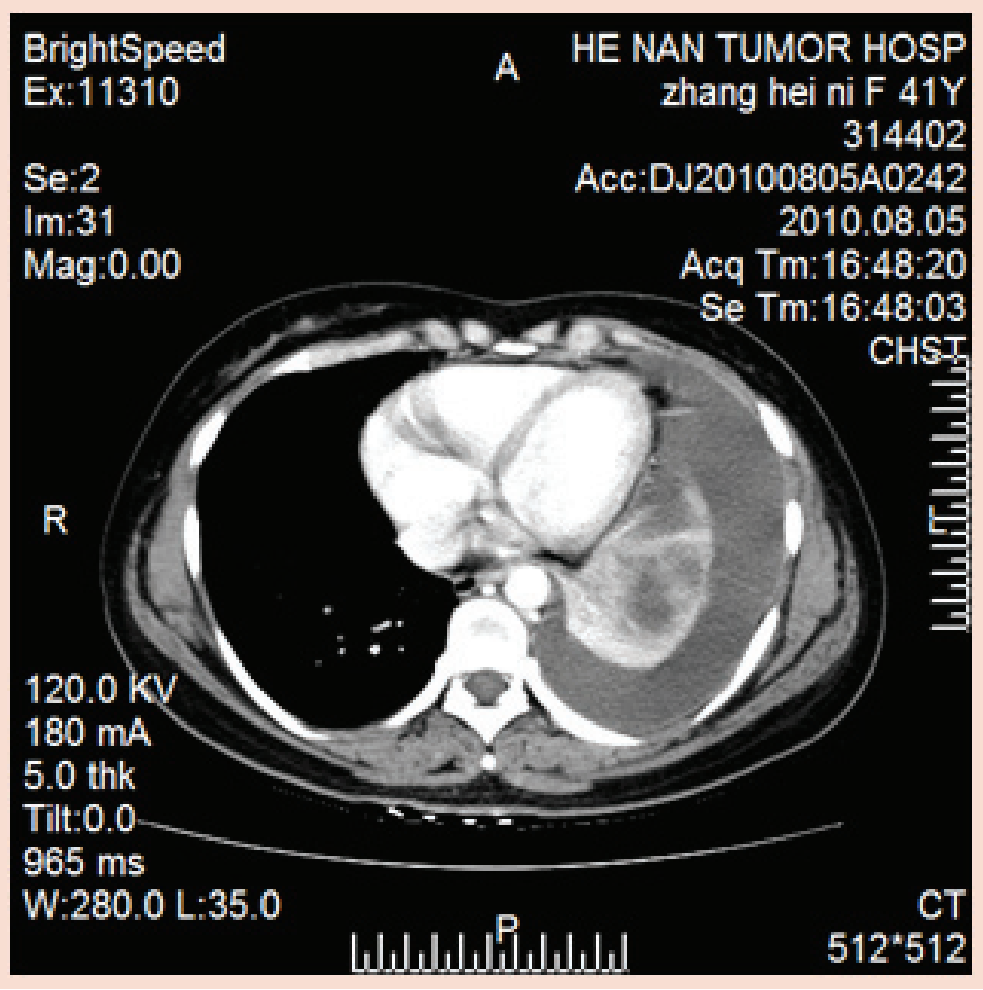

Figure 1. The primary image of the patient's CT scan.

In our case presentations, two women were diagnosed lung cancer and renal malignant cancer,

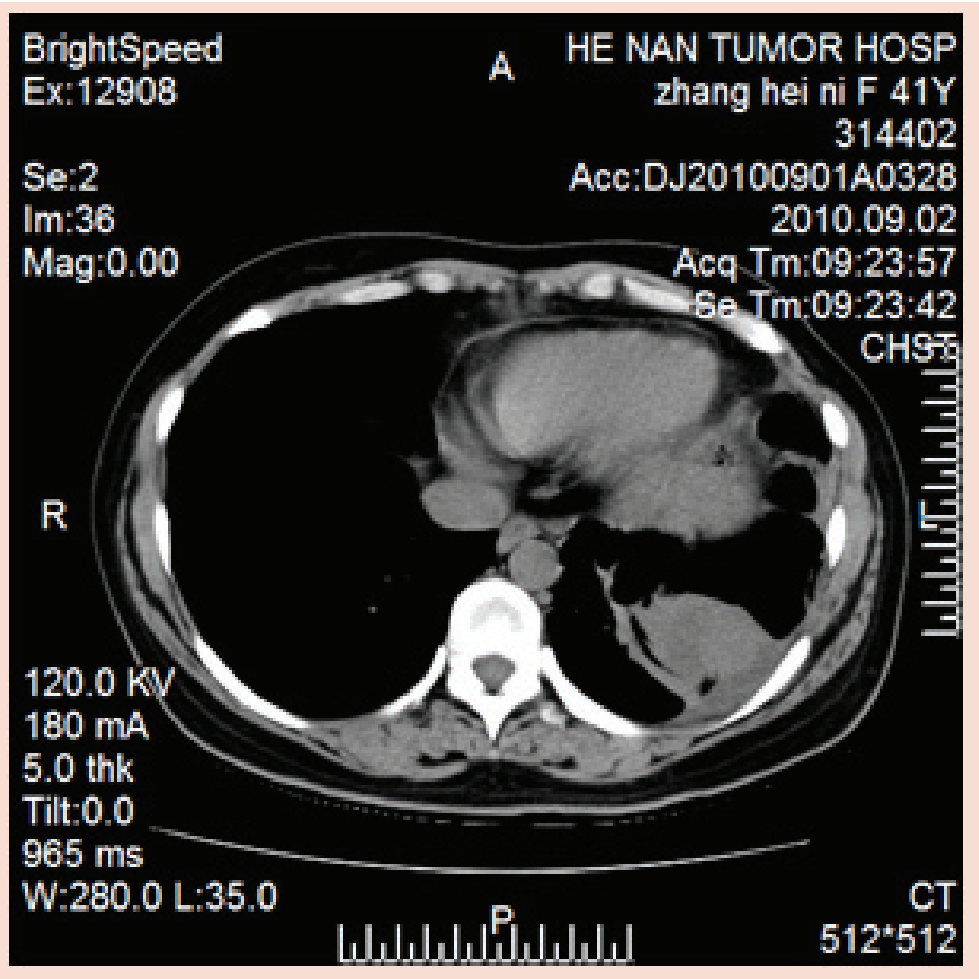

Figure 2. CT scan image after the first cycle of chemotherapy. 


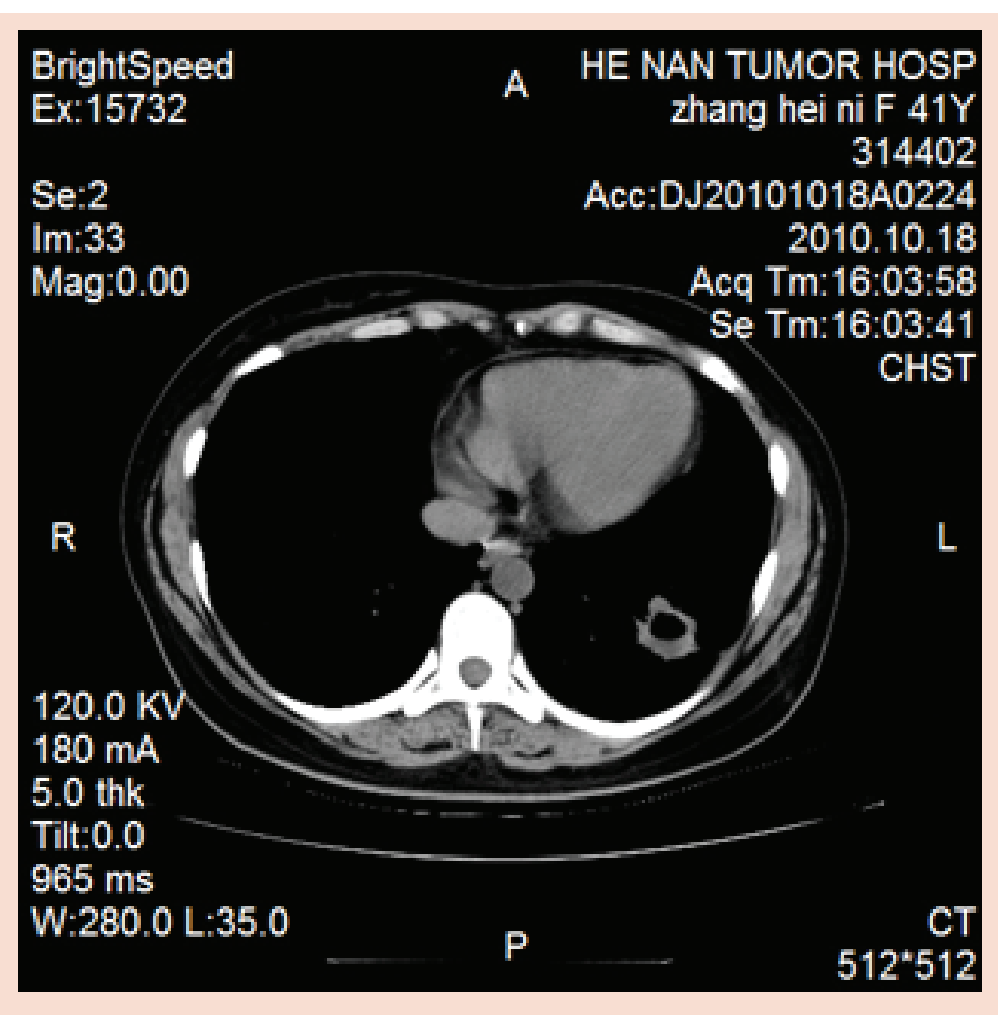

Figure 3. CT scan image after the second cycle of chemotherapy combined with cytokine-induced killer cell therapy.

respectively. Both had nearly normal platelet counts and no bleeding symptoms at their first visit. In other words, symptoms of ITP did not precede tumor diagonsis. However, when diminished platelet count, scattered petechiae and increased platelet antibodies appeared after CIK cell therapy, ITP was diagnosed. It is worthy to ponder how the autoimmune antibodies are produced and activated after CIK cell transfusion.

Pieces of evidence have implied that immune response plays an important role in the pathogenesis of ITP, which involves a complex interaction among antigen-presenting cells (APCs), T helper (Th) cells, regulatory $\mathrm{T}$ (Treg) cells and $\mathrm{B}$ cells $[39,40]$. $\mathrm{CD}^{+} \mathrm{Th}$ cells may facilitate B-cell activity and autoantibody production. It tends to show an increased Th1/Th2 ratio which always refers to the balance between IL-4 and IFN- $\gamma$ in untreated ITP patients. CD8 ${ }^{+} \mathrm{T}$ cells may prevent apoptosis of autologous megakaryocytes and lead to impaired platelet production [41].

Decreased numbers and impaired function of Treg cells, as well as the effects of cytotoxic T lymphocyte (CTL) also contribute to the pathogenesis of ITP [42]. Tregs suppress the production of cytokines by $\mathrm{CD}^{+}$and $\mathrm{CD}^{+} \mathrm{T}$ cells and limit $\mathrm{CD} 8^{+}$ T-cell cytotoxicity [43]. An increased number of Tregs has been seen in ITP patients undergoing treatment with corticosteroids [44] or rituximab [45], or the combination [46].

Clinical research discovered that CIK cell therapy may increase $\mathrm{T}$ cell subgroups $\mathrm{CD}^{+}$and $\mathrm{CD}^{+}$, decrease $\mathrm{CD}^{+}$cells, and significantly increase the ratio of $\mathrm{CD}^{+} / \mathrm{CD}^{+}$cells $[47]$. Moreover, CIK cells may decrease the $\mathrm{CD} 4{ }^{+} \mathrm{CD} 25^{+} \mathrm{CD} 127^{-}$Tregs and produce a variety of cytokines, such as IL-2, IL-4, IL-10, IL-13, IL-17, IFN- $\gamma$, TNF- $\alpha$ and TGF- $\beta$ enhancing cytotoxicity and changing the tumor microenvironment in favor of tumor eradication [48]. Increased secretion of these cytokines could be related to activation of macrophages and $B$ cells which is a known feature of ITP [6,49]. Hence, imbalance in the ratio of Th cells, decreased numbers or impaired function of Treg cells and excessive secretion of cytokine induced abnormal activation of $\mathrm{B}$ cells, may be the possible reasons for the occurrence of ITP following CIK immunotherapy. However, definitive factors responsible for ITP during and after CIK cell therapy are still elusive.

Table 1. Phenotype analysis of three transfusions of cytokine-induced killer cells.

\begin{tabular}{|llll|}
\hline Cell control & The first time & The second time & The third time \\
\hline Total cell count & $3.9 \times 10^{9}$ & $4.5 \times 10^{9}$ & $4.1 \times 10^{9}$ \\
\hline CD3 $^{+}$ & $98.2 \%$ & $97.5 \%$ & $98.7 \%$ \\
\hline $\mathrm{CD} 3^{+} \mathrm{CD} 8^{+}$ & $71.4 \%$ & $65.5 \%$ & $80.9 \%$ \\
\hline $\mathrm{CD} 3^{+} \mathrm{CD} 4^{+}$ & $17.9 \%$ & $31.0 \%$ & $9.6 \%$ \\
\hline $\mathrm{CD} 3^{+} \mathrm{CD} 56^{+}$ & $7.3 \%$ & $5.2 \%$ & $8.7 \%$ \\
\hline
\end{tabular}

Table 2. Antiplatelet antibodies detection results.

\begin{tabular}{|lll|}
\hline Items & Results & Reference values \\
\hline PAlgG & $103.4 \mathrm{ng} / 10^{7} \mathrm{PA}$ & $0-108 \mathrm{ng} / 10^{7} \mathrm{PA}$ \\
\hline PAlgM & $55.0 \mathrm{ng} / 10^{7} \mathrm{PA}$ & $0-40 \mathrm{ng} / 10^{7} \mathrm{PA}$ \\
\hline PAlgA & $19.6 \mathrm{ng} / 10^{7} \mathrm{PA}$ & $0-22 \mathrm{ng} / 10^{7} \mathrm{PA}$ \\
\hline
\end{tabular}


Table 3. Phenotype analysis of three transfusions of cytokine-induced killer cells.

\begin{tabular}{|c|c|c|c|}
\hline Cell control & The first time & The second time & The third time \\
\hline Total cell count & $3.9 \times 10^{9}$ & $4 \times 10^{9}$ & $3.9 \times 10^{9}$ \\
\hline $\mathrm{CD}^{+}$ & $97.5 \%$ & $98.1 \%$ & $98.5 \%$ \\
\hline $\mathrm{CD}^{+}{ }^{+} \mathrm{CD} 8^{+}$ & $73.4 \%$ & $78.5 \%$ & $69.9 \%$ \\
\hline $\mathrm{CD}^{+}{ }^{+} \mathrm{CD} 4^{+}$ & $21.9 \%$ & $24.7 \%$ & $30.6 \%$ \\
\hline $\mathrm{CD}^{+}{ }^{+} \mathrm{CD} 56^{+}$ & $8.4 \%$ & $7.6 \%$ & $10.6 \%$ \\
\hline
\end{tabular}

Table 4. Antiplatelet antibodies detection results.

\begin{tabular}{|lll|}
\hline Items & Results & Reference values \\
\hline PAlgG & $300.0 \mathrm{ng} / 10^{7} \mathrm{PA}$ & $0-108 \mathrm{ng} / 10^{7} \mathrm{PA}$ \\
\hline PAlgM & $2.9 \mathrm{ng} / 10^{7} \mathrm{PA}$ & $0-40 \mathrm{ng} / 10^{7} \mathrm{PA}$ \\
\hline PAlgA & $40.0 \mathrm{ng} / 10^{7} \mathrm{PA}$ & $0-22 \mathrm{ng} / 10^{7} \mathrm{PA}$ \\
\hline
\end{tabular}

Treatment is rarely required if the platelet count is above $50 \times 10^{9} / \mathrm{l}$. If the platelet count falls below $30 \times 10^{\%} / 1$, treatment should be administered based on patient's age, bleeding conditions and other associated medical conditions [5]. Corticosteroids remain the most commonly used first-line therapy for ITP, and more than $80 \%$ of patients respond to corticosteroids $[5,50]$. In our cases, the CIK cell therapy was stopped once they were diagnosed with ITP. One patient received corticosteroids due to an extremely low platelet count and bleeding risk. After which, the patient's platelet count recovered immediately. The other patient discontinued the CIK treatment no further treatment and their platelet count also increased.

In conclusion, it is reported for the first time that CIK cell therapy is associated with ITP. More cases need found and studied to help confirm and understand the relationship, etiology and mechanism between CIK and ITP. Though clinicians should be aware of some potential or unnoticed side effects of CIK cell therapy, such as ITP, this is still quite rare. CIK cell therapy remains a safe and effective method for cancer treatment.

Financial \& competing interests disclosure

The authors have no relevant affiliations or financial involve- ment with any organization or entity with a financial interest in or financial conflict with the subject matter or materials discussed in the manuscript. This includes employment, consultancies, honoraria, stock ownership or options, expert testimony, grants or patents received or pending, or royalties.

No writing assistance was utilized in the production of this manuscript.

\section{Ethical conduct of research}

The authors state that they have obtained appropriate institutional review board approval or have followed the principles outlined in the Declaration of Helsinki for all human or animal experimental investigations. In addition, for investigations involving human subjects, informed consent has been obtained from the participants involved.

\section{Informed consent disclosure}

The authors state that they have obtained verbal and written informed consent from the patient/patients for the inclusion of their medical and treatment history within this case report.

\section{Open access}

This work is licensed under the Attribution-NonCommercialNoDerivatives 4.0 Unported License. To view a copy of this license, visit http://creativecommons.org/licenses/by-nc$n d / 4.0 /$

\section{Executive summary}

- Idiopathic thrombocytopenic purpura (ITP) is an autoimmune condition occasionally associated with solid tumor.

- Cytokine-induced killer (CIK) cell therapy is a minor toxic immunotherapy method of cancer treatment as we thought before.

- Our report draws attention to the occurrence of ITP following CIK cell therapy for the first time.

- Imbalance ratio of Th cells, decreased numbers or impaired function of Treg cells and excessive secretion of cytokine induced abnormal activation of B cells, may be the possible reasons.

- More cases need to be studied to confirm the mechanisms between ITP and CIK. 


\section{References}

Papers of special note have been highlighted as:

- of interest; $\bullet \bullet$ of considerable interest.

1 Terrell DR, Beebe LA, Vesely SK et al. The incidence of immune thrombocytopenic purpura in children and adults: a critical review of published reports. Am. J. Hematol. 85(3), 174-180 (2010).

2 Cines DB, Bussel JB, Liebman HA et al. The ITP syndrome: pathogenic and clinical diversity. Blood 113, 6511-6521 (2009).

3 Neylon AJ, Saunders PW, Howard MR et al. On behalf of the Northern Region Haematology Group. Clinically significant newly presenting autoimmune thrombocytopenic purpura in adults: a prospective study of a population-based cohort of 245 patients. Brit. J. Haematol. 122, 966-974 (2003).

4 Rodeghiero F, Stasi R, Gernsheimer T et al. Standardization of terminology, definitions, and outcome criteria in immune thrombocytopenic purpura (ITP) in adults and children. Report from an international working group. Blood 113, 2386-2393 (2009).

5 Provan D, Stasi R, Newland AC et al. International consensus report on the investigation and management of primary immune thrombocytopenia. Blood. 115, 168-186 (2010).

6 Coopamah MD, Garvey MB, Freedman J et al. Cellular immune mechanisms in autoimmune thrombocytopenic purpura: an update. Transfus. Med. Rev. 1769-1780 (2003).

7 Berchtold P, Wenger M. Autoantibodies against platelet glycoproteins in autoimmune thrombocytopenic purpura: their clinical significance and response to treatment. Blood 81, 1246-1250 (1993).

- Provides the diagnosis criteria of idiopathic thrombocytopenic purpura (ITP) and the common side effects of cytokine-induced killer (CIK) cell therapy.

8 Houwerzijl EJ, Blom NR, van der Want JJ et al. Ultrastructural study shows morphologic features of apoptosis and para-apoptosis in megakaryocytes from patients with idiopathic thrombocytopenic purpura. Blood 103(2), 500-506 (2004).

9 Torre LA, Bray F, Siegel RL et al. Global cancer statistics, 2012. CA Cancer J. Clin. 65(2), 87-108 (2015).

10 Peffault de Latour R, Des Guetz G et al. Breast cancer associated with idiopathic thrombocytopenic purpura: a single center series of 10 cases. Am. J. Clin. Oncol. 27, 333-336 (2004).

11 Santivasi WL, Routt MM, Terando AM. Idiopathic thrombocytopenic purpura after mastectomy and axillary lymph node dissection. Case Rep. Surg. 2014 , 316064 (2014).

12 Khasraw M, Baron-Hay S. Immune thrombocytopenic purpura (ITP) and breast cancer. Does adjuvant therapy for breast cancer improve platelet counts in ITP? Ann. Oncol. 20, 1282-1283 (2009).

13 Ustun C, Dainer P, Hendricks L et al. Association of breast cancer and immune thrombocytopenic purpura. South. Med. J. 95, 1335-1337 (2002).

14 Terashita S, Hirano K, Hirai T et al. Successful treatment of small cell lung cancer with secondary immune thrombocytopenic purpura. Nihon Kokynki Gakkai Zasshi 47(11), 1036-1040 (2009).

15 Chibana K, Touyama M, Fujita J. A case of lung cancer with idiopathic thrombocytopenic purpura effectively treated for Helicobacter pylori. Nihon Kokyuki Gakkai Zasshi. 45(12), 992-996 (2007).

16 Nakajima T, Iyoda A, Iizasa $T$ et al. Surgical treatment of a superior sulcus tumor in a patient with idiopathic thrombocytopenic purpura: report of a case. Surg. Today 35, 1078-1080 (2005).

17 Tsoussis S, Ekonomidou F, Vourliotaki E et al. Successful treatment of idiopathic thrombocytopenic purpura-like syndrome in a cancer patient with low-dose interferon: case report and review of the literature. Am. J. Hematol. 76, 353-359 (2004).

18 Krauth MT, Puthenparambil J, Lechner K. Paraneoplastic autoimmune thrombocytopenia in solid tumors. Crit Rev Oncol Hematol. 81(1), 75-81 (2012).

19 Kubota Y, Horie K, Nagai S et al. Laparoscopic left partial nephrectomy for renal cell carcinoma associated with ITP with platelet count of 10,000/ $\mu$ l. Hinyokika Kiyo 59(12), 785-789 (2013).

20 Cho Eun Ju, Lee Ha Jung, Park Kyung Un et al. Immune thrombocytopenic purpura in a patient with renal cell carcinoma. Korean J. Intern. Med. 29, 671-674 (2014).

21 Allard JE, McBroom JW, Zahn CM et al. Vaginal metastasis and thrombocytopenia from renal cell carcinoma. Gynecol. Oncol. 92, 970-973 (2004).

22 Yoshinaga A, Hayashi T, Ohno R et al. A case of renal cell carcinoma associated with idiopathic thrombocytopenic purpura. Hinyokika Kiyo 51, 377-380 (2005).

23 Mellman I, Coukos G, Dranoff G. Cancer immunotherapy comes of age. Nature 480(7378), 480-489 (2011).

24 Hontscha C, Borck Y, Zhou H et al. Clinical trials on CIK cells: first report of the international registry on CIK cells (IRCC). J. Cancer Res. Clin. Oncol. 137(2), 305-310 (2011).

- Provides the diagnosis criteria of ITP and the common side effects of CIK cell therapy.

25 Laport GG, Sheehan K, Baker J et al. Adoptive immune therapy with cytokine-induced killer cells for patients with relapsed hematologic malignancies after allogeneic hematopoie- tic cell transplantation. Biol Blood Marrow Transplant. 17(11), 1679-1687 (2011).

- Provides the diagnosis criteria of ITP and the common side effects of CIK cell therapy.

26 Sarpatwari A, Bennett D, Logie JW et al. Thromboembolic events among adult patients with primary immune thrombocytopenia in the United Kingdom General Practice Research Database. Haematologica 95, 1167-1175 (2010).

27 Severinsen MT, Engebjerg MC, Farkas DK et al. Risk of venous thromboembolism in patients with primary chronic immune thrombocytopenia: a Danish population-based cohort study. Br. J. Haematol. 152(3), 360-362 (2011).

28 Schwartz RS. Immune thrombocytopenic purpura-From agony to agonist. N. Engl. J. Med. 357, 2299-2301 (2007). 
Toltl LJ, Nazi I, Jafari R et al. Piecing together the humoral and cellular mechanisms of immune thrombocytepenia. Semin. Thromb. Hemost. 37(6), 631-639 (2011). Stasi R. Pathophysiology and therapeutic options in primary immune thrombocytopenia. Blood Transfus. 9, 262-273 (2011).

31 McMillan R. Antiplatelet antibodies in chronic immune thrombocytopenia and their role in platelet destruction and defective platelet production. Hematol. Oncol. Clin. North. Am. 23(6), 1163-1175 (2009).

32 Lee JH, Lee J-H, Lim Y-S et al. Adjuvant Immunotherapy with Autologous Cytokine- induced Killer Cells for Hepatocellular Carcinoma. Gastroenterology S0016-5085(15) 00305-00304 (2015). immunotherapy with cytokine-induced killer cells in patients with locally advanced gastric cancer. Cancer Immunol. Immunother. 61, 2251-2259 (2012). induced killer cells as an adjuvant treatment for advanced gastric carcinoma: a retrospective study of 165 patients. Cancer Biother. Radiopharm. 28, 303-309 (2013).

35 Wang ZX, Li JL, Cao JX et al. Cytokine-induced killer cells in the treatment of patients with renal cell carcinoma: a pooled meta-analysis. Immunotherapy 6(6), 787-795 (2014).

Zhang J, Zhu L, Du H et al. Autologous cytokine- induced killer cell therapy in lung cancer patients: A retrospective study. Biomed. Pharmacother. 70, 248-252 (2015).

37 Zhang Y, Xia L, Zhang Y et al. Analysis of adverse events following the treatment of autologous cytokine induced killer cells for adoptive immunotherapy in malignant tumour sufferers. Expert Opin. Biol. Ther. 15(4), 481-493 (2015).

- Provides the diagnosis criteria of ITP and the common side effects of CIK cell therapy.

38 Li XD, Xu B, Wu J et al. Review of Chinese clinical trials on CIK cell treatment for malignancies. Clin. Transl. Oncol. 14(2), 102-108 (2012).

39 Godeau B. B-cell depletion in immune thrombocytopenia. Semin. Hematol. 50 (Suppl. 1), S75-S82 (2013).

40 Nishimoto T, Satoh T, Takeuchi T et al. Critical role of $\mathrm{CD} 4{ }^{(+)} \mathrm{CD} 25^{(+)}$regulatory $\mathrm{T}$ cells in preventing murine autoantibody-mediated thrombocytopenia. Exp. Hematol. 40, 279-289 (2012).

41 Li S, Wang L, Zhao C et al. CD8 + T cells suppress autologous megakaryocyte apoptosis in idiopathic thrombocytopenic purpura. Br. J. Haematol. 139(4), 605-611 (2007).

- Indicate some possible mechanisms of CIK cell associated ITP occurrence in our immune system.

42 Nishimoto T, Kuwana M. CD $4^{+} \mathrm{CD} 25^{+}{ }^{+}$oxp $3{ }^{+}$regulatory T cells in the pathophysiology of immune thrombocytopenia. Semin. Hematol. 50 (Suppl. 1), S43-S49 (2013).

43 Mellanby RJ, Thomas DC, Lamb J. Role of regulatory T-cells in autoimmunity. Clin Sci (Lond). 116(8), 639-649 (2009)

- Indicate some possible mechanisms of CIK cell associated ITP occurrence in our immune system.

44 Ling Y, Cao X, Yu Z et al. Circulating dendritic cells subsets and $\mathrm{CD}^{+}{ }^{+} \mathrm{Foxp}^{+}{ }^{+}$regulatory $\mathrm{T}$ cells in adult patients with chronic ITP before and after treatment with high-dose dexamethasome. Eur. J. Haematol. 79(4), 310-316 (2007).

45 Stasi R, Cooper N, Del Poeta G et al. Analysis of regulatory T-cell changes in patients with idiopathic thrombocytopenic purpura receiving B cell-depleting therapy with rituximab. Blood 112(4), 1147-1150 (2008).

46 Li Z, Mou W, Lu G et al. Low-dose rituximab combined with short-term gluco- corticoids up-regulates Treg cell levels in patients with immune thrombocytopenia. Int. J. Hematol. 93(1), 91-98 (2011).

47 Sakakura M, Wada H, Tawara I et al. Reduced Cd4+ $\mathrm{Cd} 25+\mathrm{T}$ cells in patients with idiopathic thrombocytopenic purpura. Thromb. Res. 120(2), 187-193 (2007).

-• Indicate some possible mechanisms of CIK cell associated ITP occurrence in our immune system.

48 Godfrey DI, McCluskey J, Rossjohn J. CD1d antigen presentation: Treats for NKT cells. Nat. Immunol. 6 , 754-756 (2005).

- Indicate some possible mechanisms of CIK cell associated ITP occurrence in our immune system.

49 Talaat RM, Elmaghraby AM, Barakat SS et al. Alterations in immune cell subsets and their cytokine secretion profile in childhood idiopathic thrombocytopenic purpura (ITP). Clin. Exp. Immunol. 176(2), 291-300 (2014).

50 Mazzucconi MG, Fazi P, Bernasconi S et al. Therapy with high-dose dexamethasone (HD-DXM) in previously untreated patients affected by idiopathic thrombocytopenic purpura: a GIMEMA experience. Blood 109, 1401-1407 (2007) 
